The second group of doctors referred to by $\mathrm{Dr}$ Jarrett includes many of those unable to obtain senior registrar posts in the past. Indications are that the number of applicants for higher training posts are falling and many of these doctors could now be successful in obtaining specialist registrar posts. JCHPT would no doubt advise whether in these cases a shorter period of higher training could lead to the award of the Certificate of Completion of Higher Specialist Training and so allow them to apply for consultant posts. College regional advisers and others are already able to offer career advice to such colleagues.

The College will be energetically using the new workforce planning procedures to ensure an adequate number of both full-time and part-time training posts are available to ensure a supply of well-trained applicants for consultant posts.

DAvid STORER, Chairman, College Manpower Committee, Royal College of Psychiatrists

Sir: Dr Jarrett, in common with many other people, is concerned about the inability to recruit fully trained consultant psychiatrists in many parts of the country. This is clearly related to the inadequate senior registrar numbers. Dr Jarrett's second paragraph would, I believe, not be acceptable to government since they have firmly set their face against the idea that doctors qualified outside the European community can enter and have permanent careers in medicine in this country. Doctors from the European Union are of course eligible to enter the country for training or permanent posts.

Dr Jarrett's second suggestion of a 'rehabilitation' course for locum doctors has been considered by the College. I think it is fair to say that there is a good deal of sympathy for doctors in this position who wish to enter substantive consultant posts but at the present time, with queues of qualified registrars waiting to join higher psychiatric training, it would require a separate 'stream' of higher psychiatric training so that such doctors did not have to compete with others straight off MRCPsych training schemes. The Department of Health appear to see this as a way of circumventing manpower planning. However, even they are now beginning to see the extreme damage which is being caused to the service by their previously inadequate vision of the needs for consultant manpower. Perhaps they could be persuaded that Dr Jarrett's arguments have validity. We can but try.

C. Thompson, Registrar, Royal College of Psychiatrists

\section{Clash of the Titans}

Sir: At last, in your May 1995 issue, the clash of Titans, Azuonye and Culliford! (Azuonye, 1995; Culliford, 1995).

I must confess that I have sometimes had difficulty in following Dr Culliford's reasoning and have even wondered whether the title 'Wisdom' was, perhaps, a trifle pretentious. But then it occurred to me that were a piece of great pottery to be included in an MRCPsych examination paper, it would probably be described by the candidates as showing classical schizophrenic thought disorder, and I realised that my difficulty in understanding him merely reflected my own lack of imagination. I certainly do not object to your continuing to publish Dr Culliford's pieces, provided that it is made clear that they are not College policy statements.

I have never experienced the same difficulty in understanding Dr Azuonye's numerous letters in your columns. However, I would like to point out that a few years ago Dr Azuonye wrote a book (Azuonye, 1992) in which he suggested, inter alia, that the United States, Mexico and Canada should unite to form the United States of North America, that there should be no further immigration into that country and that its borders should be partially sealed with close monitoring of all air- and seagoing traffic, that the punishment for causing death by dangerous driving should be at least $\mathbf{4 0}$ years in jail, that a deadline should be set for the abolition of the internal combustion engine and that research should be concentrated on the use of the "natural energles contained within the electro-magnetic spectrum, including our planet's force flelds as sources of energy ..... It was also proposed that all political parties should be abolished, that all borrowing of money, both governmental and individual, be forbidden, and that professional sport be terminated.

I therefore conclude that when Dr Azuonye accuses Dr Culliford of offering a superficial and simplistic picture of the nature of things, 